\title{
Seed germination in Cerrado species
}

\author{
Lilian B. P. Zaidan ${ }^{1, *}$ and Rosana C. Carreira ${ }^{2}$
}

${ }^{1}$ Seção de Fisiologia e Bioquímica de Plantas, Instituto de Botânica, Caixa Postal 3005, 01061-970 São Paulo, SP, Brasil. ${ }^{2}$ Universidade Cruzeiro do Sul (UNICSUL), Av. Dr. Ussiel Cirilo, 225, CBS, 08060-070 São Paulo, SP, Brasil. *Corresponding author: lilianzaidan@uol.com.br

Received: 26 August 2008; Accepted: 31 October 2008

The aim of this review is to comment on the available data about germination of seeds from herb, shrub and tree species of the Cerrado after the publication of the review written by Felippe and Silva in 1984. Studies on seed germination of herbaceous species focused mainly on the responses of seeds to light, different ranges of temperature and storage in the soil. The majority of seeds from herb species germinate between $20^{\circ} \mathrm{C}$ and $30^{\circ} \mathrm{C}$, and are photoblastic. Alternate temperatures favored germination in some seeds, but changed light sensitivity of the achenes of Bidens gardneri. Seeds of most of the shrub species of Melastomataceae are positive photoblastic; among the Velloziaceae, germination in the dark was observed in some species. Other shrub species show dormancy caused by impermeability of the seed tegument, as described for seeds of some species of Bauhinia. Their dormancy is broken by chemical scarification using sulphuric acid. Seeds of Heteropterys pteropetala are sensitive to very high temperatures, similar to those registered during burnings. Some species were considered to have allelopathic effects and could inhibit the germination of seeds of other species and the establishment of plantlets. Seeds of most tree species do not require light to germinate and the focus of the studies were on methods of dormancy breaking. Sulphuric acid and incisions in the tegument proved to be the most efficient methods to break dormancy. In general, the studies are limited to three major aspects: responses to light, effects of different temperatures and dormancy breaking. More studies are necessary to understand the physiological and biochemical aspects of reserve compounds and their mobilization during germination, as well as the effects of fire in these seeds.

Key words: dormancy, photoblastism, soil seed bank, temperature

Germinação de sementes de espécies de Cerrado: O objetivo desta revisão é comentar dados disponíveis sobre a germinação de sementes de espécies herbáceas, arbustivas e arbóreas do Cerrado, desde a publicação da revisão feita por Felippe e Silva na década de 1980. Estudos de germinação de sementes de espécies herbáceas do Cerrado enfatizam as respostas das sementes à luz, temperatura e armazenamento no solo. A maioria dessas sementes germina entre $20^{\circ} \mathrm{C}$ e $30^{\circ} \mathrm{C}$ e são fotoblásticas. Temperaturas alternadas nem sempre favoreceram a germinação das sementes, no entanto, alteraram a sensibilidade à luz em aquênios de Bidens gardneri. A maioria das sementes das espécies arbustivas de Melastomataceae estudadas apresentaram fotoblastismo positivo; entre as Velloziaceae, foi observada germinação no escuro em algumas espécies. Sementes de algumas espécies arbustivas possuem dormência causada pela impermeabilidade do tegumento, quebrada com imersão em ácido sulfúrico, como no gênero Bauhinia. Sementes de Heteropterys pteropetala são sensíveis a temperaturas altas, similares àquelas registradas durante as queimadas. Plantas de algumas espécies têm efeitos alelopáticos e podem inibir a germinação de sementes de outras espécies e o estabelecimento de plântulas. A maioria das sementes de espécies arbóreas não requer luz para germinar e grande parte dos estudos teve como objetivo testar métodos de quebra de dormência. Os métodos mais eficazes para a quebra dos diferentes tipos de dormência foram passagem por ácido sulfúrico e incisões no tegumento das sementes. Em termos gerais, os estudos realizados limitaram-se a três aspectos: fotoblastismo, temperatura e quebra de dormência. Ainda há grande falta de dados para o entendimento dos aspectos fisiológicos e bioquímicos da composição e mobilização das reservas das sementes e do efeito do fogo na germinação dessas sementes. Palavras-chave: banco de semente do solo, dormência, fotoblastismo, temperatura 


\section{INTRODUCTION}

The Cerrado, the second largest biome in Brazil after the Amazon forest, hosts a high biodiversity and is listed as one of the 34 most endangered ecosystems (hotspots) of the world (Mittermeier et al., 1999). The cerrado vegetation is constituted basically by two distinct components, a tree/shrub and an herbaceous/subshrub stratum, this latter one comprising more than double the number of tree species. Some authors claim that herb species may account for approximately $80 \%$ of the flora (Mantovani and Martins, 1988; Coutinho, 2002).

The woody component presents root systems that allow the plants to reach deep soil layers with permanent water availability while the herbaceous component is formed by perennial species with well developed underground organs, such as rhizomes, bulbs, xylopodia and tuberous roots that guarantee their survival during the dry period and occasional fire events. These underground reserve organs act also as reproductive structures and for many years plant reproduction in the cerrado was considered to be only vegetative, since seed germination was thought to occur only under unique circumstances (Ferri, 1960). Later on, it was shown that the germination of seeds in the Cerrado was a relatively common feature and seedlings of 50 woody species were found growing in the cerrados (Labouriau et al., 1963, 1964; Válio and Moraes, 1966). The early studies on seed germination of Cerrado species were reviewed by Felippe and Silva (1984). Since this review, several additional studies appeared in the current literature, most of them describing seed requirements for germination and storage conditions. At the end of the 1990's studies on cerrado soil seed banks attracted the interest of some investigators and a few data were published (Sassaki et al., 1999a, b, c; Pereira-Diniz and Ranal, 2006; Araújo and Cardoso, 2006, 2007).

Within the Cerrado biome, the vegetation known as "campos rupestres" is considered to host a number of endemic and threatened species (Lara and Fernandes, 1996). Studies carried out in the Serra do Cipó (Minas Gerais State, Brazil) allowed us to conclude that the plants from this vegetation are well adapted to the environmental stress conditions they are subjected to, such as high exposure to sunlight and to large variations in temperature not only during summer/winter, but also during the day-time. They are also growing in dry and shallow soils which are poor in mineral and organic nutrients (Giulietti et al., 1987). In recent years, special attention was given to the germination of seeds of plants of the Serra do Cipó. Most of the plants that had their seed germination investigated are herbs or shrubs and many of them are considered as endangered species. They belong mostly to the Asteraceae, Eriocaulaceae, Fabaceae, Lythraceae, Melastomataceae, Velloziaceae and Xyridaceae.

The aim of this review is to comment on the results obtained since the publication of Felippe and Silva's review (1984). We did not include in this review data about the germination of seeds from species of Riverine Forests, Deciduous and Semideciduous Forests. Although there is a considerable amount of important results in $\mathrm{PhD}$ theses and of data presented in scientific meetings, we decided to consider only the studies effectively converted in scientific papers. It must be mentioned the contribution of the "Rede de Sementes do Cerrado” (Salomão et al., 2003), with the publication of a valuable guide for all those interested in the germination of seeds of this biome (www.rededesementes docerrado. com.br). To facilitate for the reader, the species that had their seeds investigated were separated into herbaceous, shrub/subshrub and tree species, as defined by Radford et al. (1976).

\section{HERBACEOUS SPECIES}

The Poaceae constitutes the most representative family in the Cerrado. Nevertheless, there is a lack of information about the germination of seeds of native cerrado grasses, probably due to their successful vegetative propagation. So far, the Asteraceae are the best represented plant group in studies on seed germination of herbaceous species (Table 1), followed by the Xyridaceae, Eriocaulaceae and Velloziaceae. Some species of these three latter families are endemic to the Serra do Cipó (Minas Gerais State, Brazil). The seeds usually require light to germinate, except for Vellozia epidendroides Mart. ex Schult. \& Schult., described as negatively photoblastic, according to Garcia et al. (2007).

The achenes of Bidens gardneri Baker (Asteraceae) can be separated in short, medium and long achenes. The short achenes are located in the margins of the capitulum and show lower germinability when compared to long 
Table 1. Light/dark requirement, type of dormancy and/or characteristics of seeds of herbaceous species of the Cerrado.

\begin{tabular}{|c|c|c|c|c|}
\hline Species & Family & $\begin{array}{l}\text { Light/Dark } \\
\text { requirement }\end{array}$ & $\begin{array}{l}\text { Type of dormancyand/or } \\
\text { other characteristics }\end{array}$ & Reference \\
\hline $\begin{array}{l}\text { Bidens gardneri } \\
\text { Baker }\end{array}$ & Asteraceae & $\begin{array}{l}\text { light } \\
\text { (nonphotoblastic } \\
\text { under alternate } \\
\text { temperatures) }\end{array}$ & $\begin{array}{l}\text { germination \% is } \\
\text { higher in longer } \\
\text { achenes; high \% } \\
\text { of germination in } \\
\text { light is maintained } \\
\text { during } 6 \text { month } \\
\text { storage at } 4^{\circ} \mathrm{C} \text { and } \\
\text { decreases to } 60 \% \\
\text { after } 9 \text { month } \\
\text { storage }\end{array}$ & $\begin{array}{l}\text { Felippe (1990a); } \\
\text { Sassaki et al. (1999a); } \\
\text { Sassaki et al. (1999b) }\end{array}$ \\
\hline $\begin{array}{l}\text { Dychia tuberosa (Vell.) } \\
\text { Beer }\end{array}$ & Bromeliaceae & indifferent & $\begin{array}{l}\text { optimum temperature } \\
\text { between } 30^{\circ} \mathrm{C} \text { and } 35^{\circ} \mathrm{C}\end{array}$ & Vieira et al. (2007) \\
\hline $\begin{array}{l}\text { Eremanthus } \\
\text { elaeagnus (C. Martius } \\
\text { ex DC.) Schultz-Bip; E. } \\
\text { glomerulatus Less.; E. } \\
\text { incanus (Less.) Less. }\end{array}$ & Asteraceae & indifferent & $\begin{array}{l}\text { campo rupestre; } \\
\text { germination \% is low, } \\
\text { due mainly to absence } \\
\text { of embryos; alternate } \\
\text { temperature did not } \\
\text { promote germination }\end{array}$ & Velten and Garcia (2005) \\
\hline $\begin{array}{l}\text { Paepalanthus } \\
\text { specious Koern. }\end{array}$ & Eriocaulaceae & light & $\begin{array}{l}\text { campo rupestre; } \\
\text { thermo-resistant } \\
\left(80^{\circ} \mathrm{C} \text { for } 30 \mathrm{~min}\right)\end{array}$ & $\begin{array}{l}\text { Sá e Carvalho and } \\
\text { Ribeiro (1994) }\end{array}$ \\
\hline $\begin{array}{l}\text { Psychotria } \\
\text { barbiflora DC. }\end{array}$ & Rubiaceae & $\begin{array}{c}\text { light (newly } \\
\text { collected )/ } \\
\text { indifferent (after } \\
\text { storage in soil) }\end{array}$ & $\begin{array}{l}\text { low germination \% } \\
\text { when stored at } 4^{\circ} \mathrm{C} \\
\text { and in cerrado soil }\end{array}$ & Sassaki et al. (1999a) \\
\hline $\begin{array}{l}\text { Schizocentron } \\
\text { elegans Meissn. }\end{array}$ & Melastomataceae & light & $\begin{array}{l}\text { germination \% is } \\
\text { higher between } 20^{\circ} \mathrm{C} \\
\text { and } 30^{\circ} \mathrm{C}\end{array}$ & $\begin{array}{l}\text { Carreira and Zaidan } \\
\text { (2007) }\end{array}$ \\
\hline $\begin{array}{l}\text { Syngonanthus elegans } \\
\text { (Bong.) Ruhland; } \text { S. } \\
\text { elegantulus Ruhland; } \\
\text { S. venustus Silveira; }\end{array}$ & Eriocaulaceae & light & $\begin{array}{l}\text { campo rupestre; } \\
\text { alternate temperatures } \\
\text { favour germination; }\end{array}$ & $\begin{array}{l}\text { Oliveira and Garcia } \\
\text { (2005) }\end{array}$ \\
\hline $\begin{array}{l}\text { S. nitens (Bong.) } \\
\text { Ruhland }\end{array}$ & & & $\begin{array}{l}\text { acidity and hypoxia do } \\
\text { not affect germination }\end{array}$ & Schmidt et al. (2008) \\
\hline $\begin{array}{l}\text { Tibouchina gracilis } \\
\text { (Bonpl.) Cogn. }\end{array}$ & Melastomataceae & light & $\begin{array}{l}\text { germination \% is higher } \\
\text { under light and } \\
\text { between } 20^{\circ} \mathrm{C} \text { and } 30^{\circ} \mathrm{C}\end{array}$ & $\begin{array}{l}\text { Carreira and Zaidan } \\
\text { (2007) }\end{array}$ \\
\hline $\begin{array}{l}\text { Vellozia glandulifera } \\
\text { Goethart \& Henrard; } \\
\text { V. variabilis Mart } \\
\text { ex Schult. \& Schult }\end{array}$ & Velloziaceae & light & $\begin{array}{l}\text { campo rupestre; seeds } \\
\text { must be exposed to high } \\
\text { light intensities }\end{array}$ & Garcia and Diniz (2003) \\
\hline $\begin{array}{l}\text { Vellozia epidendroides } \\
\text { Mart ex Schult. } \\
\text { \& Schult. }\end{array}$ & Velloziaceae & indifferent & $\begin{array}{l}\text { campo rupestre; may } \\
\text { form soil seed banks; } \\
\text { germinates at different } \\
\text { temperatures and light } \\
\text { conditions }\end{array}$ & Garcia et al. (2007) \\
\hline $\begin{array}{l}\text { Vernonia cognata } \\
\text { Less. }\end{array}$ & Asteraceae & indifferent & $\begin{array}{l}\text { achenes are viable for } \\
\text { over } 18 \text { months if stored } \\
\text { at } 4^{\circ} \mathrm{C} \text { but lose viability }\end{array}$ & $\begin{array}{l}\text { Cesarino and Zaidan } \\
\text { (1998) }\end{array}$ \\
\hline
\end{tabular}




\begin{tabular}{|c|c|c|c|c|}
\hline & & & $\begin{array}{l}\text { after } 10 \text { month storage at } \\
\text { room temperature }\end{array}$ & \\
\hline $\begin{array}{l}\text { V. herbacea(Vell.) } \\
\text { Rusby }\end{array}$ & Asteraceae & $\begin{array}{l}\text { light? (very low \% } \\
\text { of germination) }\end{array}$ & $\begin{array}{l}\text { germination of newly } \\
\text { collected seeds was } 11 \% \\
\text { in light and } 3 \% \text { in the dark } \\
\text { after } 25 \text { days; only } 15 \% \text { of } \\
\text { the achenes have embryos } \\
\text { (tetrazolium test) }\end{array}$ & Sassaki et al. (1999a) \\
\hline $\begin{array}{l}\text { Xyris cipoensis } \\
\text { Smith \& Downs; } X . \\
\text { longiscarpa Alb. } \\
\text { Nilsson; } X . \text { platystachia } \\
\text { Alb. Nilsson; } X \text {. } \\
\text { trachyphilla Mart. }\end{array}$ & Xyridaceae & light & $\begin{array}{l}\text { campo rupestre; } \\
\text { alternate temperatures } \\
\text { did not favour germination }\end{array}$ & $\begin{array}{l}\text { Abreu and Garcia } \\
\text { (2005) }\end{array}$ \\
\hline
\end{tabular}

achenes. Germination is high under continuous light and low in darkness but increases during the period of storage (Felippe, 1990a). Achenes stored for up to six months at $4{ }^{\circ} \mathrm{C}$ showed light sensivity, but after nine months storage, the photoblastic response is lost for the shortest and longest achenes (Sassaki et al., 1999b). Alternate temperatures during storage of achenes with high moisture content followed by alternate temperatures during germination change the light sensitivity of the achenes (Rondon et al., 2001). According to the authors, this could explain the germination of the achenes during storage in the soil.

In general, studies on seed germination focus on the responses of seeds to light, different ranges of temperature, here included alternate temperatures, and storage in the soil. Seeds of the Eriocaulaceae Paepalanthus speciosus Koern. (Sá e Carvalho and Ribeiro, 1994) and of the bromeliad Dichya tuberosa (Vell.) Beer (Vieira et al., 2007) germinate more rapidly at temperatures higher than $30^{\circ} \mathrm{C}$. This could increase the capacity of the species to survive after fire. At lower temperatures, germination is very heterogeneous, leading to the formation of seedlings and plantlets at different times; plant growth and flowering will occur at different times causing a lost in the synchronisation of this process, an important condition for sexual reproduction. Nevertheless, the majority of seeds from herb species of the Cerrado and "Campos Rupestres" germinate between $20^{\circ} \mathrm{C}$ and $30^{\circ} \mathrm{C}$, as already mentioned by Felippe and Silva (1984) for Cerrado seeds. Alternate temperatures favored germination in seeds of Syngonanthus elegantulus Ruhland, S. elegans (Bong.)
Ruhland and S. venustus Silveira (Oliveira and Garcia, 2005), but had no effect on the germination of seeds of some species of Eremanthus (Velten and Garcia, 2005), Schizocentron elegans Meissn. and Tibouchina gracilis (Bonpl.) Cogn. (Carreira and Zaidan, 2007).

Another effect of alternate temperatures is to substitute the positive effects of light on the germination of photoblastic seeds, as seen in B. gaardneri, although this effect was not observed in seeds of some species of Xyris (Abreu and Garcia, 2005) and of some Melastomataceae, as seen in S. elegans and T. gracilis (Carreira and Zaidan, 2007). The period of storage, both in the soil and in refrigerator at $4^{\circ} \mathrm{C}$, affected the photoblastism of the seeds of Psychotria barbiflora DC. In this species, newly collected seeds are positively photoblastic but become indifferent to light during storage (Sassaki et al., 1999a).

Seeds (achenes) of Eremanthus ssp. and Vernonia herbacea (Vell.) Rusby show low germinability. The production of achenes by species of Eremanthus is high, but many of them do not complete their development or suffer predation by insects. In apparently viable achenes of E. elaeagnus E. glomerulatus, about $91 \%$ and $70 \%$, respectively, had no embryos (Velten and Garcia, 2005). In $V$. herbacea, $15 \%$ of the achenes did not have viable embryos according to the tetrazolium test (Sassaki et al., 1999a).

The floral scapes of Syngonanthus nitens (Bong.) Ruhland (Eriocaulaceae) are used in handcrafts, being an important source of income in the Jalapão region (State of Tocantins). For this reason, a study on the conditions that regulate the germination of these seeds was 
conducted (Schimidt et al., 2008). The authors verified that seed germinability is dependent on the time of seed production and seed dispersal. Seeds produced in September/October had higher germinability. The seeds require light to germinate and can be stored at $-20^{\circ} \mathrm{C}$. These data give important information to support the economic use of the species.

The African grasses, Melinis minutiflora Beauv and Brachiaria decumbens (Nees) Stapf. have a great competitive ability over cerrado herbaceous species and are considered the most threatening invasive plants in the biome Actually, these grasses occur in virtually every cerrado fragment, outcompeting native herbs (Klink, 1996; Pivello et al., 1999). This fact raised investigations about the possibility of the plants to have allelopathic effects. This was recently confirmed in the study carried out by Barbosa et al. (2008). The authors demonstrated that aqueous leachates of leaves and seeds of $B$. decumbens were able to inhibit the germination of seeds of test species (Lactuca sativa L.) and of other invasive plants (M. minutiflora and Phalaris canarinensis L.).

\section{SHRUB/SUBSHRUB SPECIES}

Studies on the germination of seeds of shrub and subshrub species from the Cerrado are focused mainly on the sensitivity of seeds to light and on optimum or cardinal temperatures. Effects of light and temperature are the most common methods to evaluate germination, in terms of germinability of seeds and the mean speed of germination. The germination tests are usually conducted at temperatures in the range from $15^{\circ} \mathrm{C}$ to $40^{\circ} \mathrm{C}$ at $5^{\circ} \mathrm{C}$ intervals, and sometimes under alternate temperatures $\left(30^{\circ} \mathrm{C} / 20^{\circ} \mathrm{C}\right)$ under continuous light/ darkness.

Seeds of all species belonging to the Melastomataceae that had been investigated by Carreira and Zaidan (2007) are positively photoblastic and no germination in darkness was registered. Nevertheless, Ranieri et al. (2003) and Silveira et al. (2004) observed some germination in the dark. Among the Velloziaceae, some germination in the dark was also observed (Garcia et al., 2007), as shown in Table 2.

Higher germinability was achieved at $20^{\circ} \mathrm{C}$ and $30^{\circ} \mathrm{C}$ in seeds of the Melastomataceae of the Cerrado and the Velloziaceae of the "Campos Rupestres". Temperatures of $15^{\circ} \mathrm{C}$ and $35^{\circ} \mathrm{C}$ had a negative effect on germination and this corroborates the fact that temperatures between $20^{\circ} \mathrm{C}$ and $30^{\circ} \mathrm{C}$ are favorable to start the germination process (Felippe and Silva, 1984; Melo et al., 1998). In relation to $25^{\circ} \mathrm{C}$, application of alternate temperatures did not abbreviate the time to start germination nor the germinability of the seeds of the Melastomataceae species tested.

The distribution of plants of Melastomataceae species in areas of Cerrado and "Campos Rupestres" could be influenced by the quality and quantity of light radiation that reaches the seeds. In a secondary way, temperature could affect seed germination, probably acting on the speed of the germination process. The Melastomataceae produce large amounts of small seeds with high longevity, remaining viable during years, both in laboratory conditions and buried in the soil, isolated or within the fruits (Carreira and Zaidan, 2003). In the absence of light they do not germinate and may remain dormant in the soil for long periods thus constituting soil seed banks. In fact, in the studies of soil seed banks in the Cerrado, the most common seeds were always those of the Melastomataceae (Sassaki et al., 1999a). Plants belonging to the Rubiaceae (Palicourea marcagravii St. Hil., Psychotria hoffmanseggiana (Wild. Ex Roem. \& Schutz.) Mull. Arg. and P. vellosiana Benth.) also contribute to form soil seed banks (Araújo and Cardoso, 2007). According to the authors, artificial storage in the soil favored the survival of the seeds and contributed to maintain their longevity. Production of seeds that can keep their viability for long periods in the soil is important to individuals and to a population, since it allows the colonization of a great variety of habitats (Garcia et al., 2007).

Some shrub species show dormancy caused by impermeability of the tegument of the seeds. This seems to be the case of seeds of some species of Bauhinia. In these seeds, dormacy is broken with chemical scarification using sulphuric acid (Pereira, 1992; Alves et al., 2000). Another common species of the Cerrado is Solanum lycocarpum St. Hil., common name "fruta-dolobo". The fruit is a basic component of the diet of the "lobo-guará" (Chrysocyum brachyurus Illiger) and thus, seeds are frequently found in the faeces of this animal (Dietz, 1984). Although these seeds pass through the digestive tract of the animal, thus suffering acid 
Table 2. Light/dark requirement, type of dormancy and/or characteristics of seeds of shrub/subshrub species of the Cerrado.

\begin{tabular}{|c|c|c|c|c|}
\hline Species & Family & $\begin{array}{l}\text { Light/Dark } \\
\text { requirement }\end{array}$ & $\begin{array}{c}\text { Type of dormancy and/or } \\
\text { other characteristics }\end{array}$ & Reference \\
\hline $\begin{array}{l}\text { Actinocladum } \\
\text { verticilatum (Ness) } \\
\text { McClure ex Soderstrom }\end{array}$ & Poaceae & light & $\begin{array}{l}\text { germination \% is higher } \\
\text { at } 25^{\circ} \mathrm{C}\end{array}$ & $\begin{array}{l}\text { Felippe and Filgueiras } \\
\text { (1986) }\end{array}$ \\
\hline $\begin{array}{l}\text { Andira humilis Mart. } \\
\text { ex Benth }\end{array}$ & Fabaceae & ? (unknown) & allelopathic potential & Periotto et al. (2004) \\
\hline $\begin{array}{l}\text { Baccharis } \\
\text { dracunculifolia D.C. }\end{array}$ & Asteraceae & indifferent & $\begin{array}{l}\text { campo rupestre; higher } \\
\text { EVIs in achenes } \\
\text { germinated at } 15^{\circ} \mathrm{C} \text { and } \\
20^{\circ} \mathrm{C} \text { under light and } 15^{\circ} \mathrm{C} \\
\text { in the dark }\end{array}$ & $\begin{array}{l}\text { Gomes and Fernandes } \\
\text { (2002) }\end{array}$ \\
\hline $\begin{array}{l}\text { Bauhinia forficata } \\
\text { Link. }\end{array}$ & Fabaceae & ? (unknown) & $\begin{array}{l}\text { tegument impermeability; } \\
\text { the best treatment: } 30^{\circ} \mathrm{C} \\
\text { and vermiculite }\end{array}$ & Pereira (1992) \\
\hline $\begin{array}{l}\text { B. monandra Britt.; } \\
\text { B. ungulata L. }\end{array}$ & Fabaceae & light & $\begin{array}{l}\text { tegument impermeability; } \\
\text { dormancy break: } \\
\text { scarification with } \\
\text { sulphuric acid }\end{array}$ & Alves et al. (2000) \\
\hline $\begin{array}{l}\text { Byrsonima intermedia } \\
\text { A. Juss. }\end{array}$ & Malpighiaceae & $\begin{array}{l}\text { ? (experiment } \\
\text { under } 16 \mathrm{~h} \\
\text { photoperiod) }\end{array}$ & $\begin{array}{l}\text { in vitro germination; } \\
\text { best culture media: MS } \\
\text { and WPM 50\%, without } \\
\text { sucrose }\end{array}$ & Nogueira et al. (2004) \\
\hline $\begin{array}{l}\text { Campomanesia } \\
\text { adamantium Camb. }\end{array}$ & Myrtaceae & ? (unknown) & recalcitrant & Melchior et al. (2006) \\
\hline $\begin{array}{l}\text { C. pubescens (DC.) } \\
\text { Berg. }\end{array}$ & Myrtaceae & indifferent & $\begin{array}{l}\text { ? (unknown); shorter } \\
\text { time to germinate at } 25^{\circ} \mathrm{C}\end{array}$ & $\begin{array}{l}\text { Arrigoni-Blank et al. } \\
\text { (1997) }\end{array}$ \\
\hline $\begin{array}{l}\text { Diplusodon virgatus } \\
\text { Pohl. }\end{array}$ & Lythraceae & light & $\begin{array}{l}\text { storage at } 5^{\circ} \mathrm{C} \text {; seeds } \\
\text { remain viable after } 12 \\
\text { months }\end{array}$ & Cesarino et al. (1998) \\
\hline $\begin{array}{l}\text { Heteropterys } \\
\text { pteropetala } \\
\text { (Adr. Juss.) }\end{array}$ & Malpighiaceae & indifferent & $\begin{array}{l}\text { seeds affected by } \\
\text { early-fire }\end{array}$ & Schmidt et al. (2005) \\
\hline $\begin{array}{l}\text { Lavoisiera cordata } \\
\text { Cogn. }\end{array}$ & Melastomataceae & $\begin{array}{l}\text { ? (experiment } \\
\text { under } 12 \mathrm{~h} \\
\text { photoperiod) }\end{array}$ & $\begin{array}{l}\text { campo rupestrehighest } \\
\text { radicle emergency rate at } \\
20^{\circ} \mathrm{C} \text { and above }\end{array}$ & Ranieri et al. (2003) \\
\hline L. francavillana Cogn. & Melastomataceae & $\begin{array}{l}\text { ? (experiment } \\
\text { under } 12 \mathrm{~h} \\
\text { photoperiod) }\end{array}$ & $\begin{array}{l}\text { campo rupestrehighest } \\
\text { radicle emergency rate at } \\
25^{\circ} \mathrm{C} \text { and above; }\end{array}$ & Ranieri et al. (2003) \\
\hline $\begin{array}{l}\text { Marcetia taxifolia (A. } \\
\text { St.-Hil.) DC. }\end{array}$ & Melastomataceae & light & $\begin{array}{l}\text { campo rupestre higher } \\
\text { germination } \% \text { at } 15^{\circ} \mathrm{C} \\
\text { and } 20^{\circ} \mathrm{C}\end{array}$ & Silveira et al. (2004) \\
\hline $\begin{array}{l}\text { Miconia albicans (Sw.) } \\
\text { Triana }\end{array}$ & Melastomataceae & light & $\begin{array}{l}\text { allelopathic potential; } \\
\text { forms soil seed banks; } \\
\text { germination is higher } \\
\text { under light and between } \\
20^{\circ} \mathrm{C} \text { and } 30^{\circ} \mathrm{C}\end{array}$ & $\begin{array}{l}\text { Gorla and Perez (1997); } \\
\text { Carreira and Zaidan } \\
\text { (2007) }\end{array}$ \\
\hline $\begin{array}{l}\text { M. langsdorffii Cogn.; } \\
\text { M. stenostachya Schr. } \\
\text { \& Mart. ex. DC. }\end{array}$ & Melastomataceae & light & $\begin{array}{l}\text { germination is higher } \\
\text { under light and between } \\
20^{\circ} \mathrm{C} \text { and } 30^{\circ} \mathrm{C}\end{array}$ & $\begin{array}{l}\text { Carreira and Zaidan } \\
\text { (2007) }\end{array}$ \\
\hline
\end{tabular}




\begin{tabular}{|c|c|c|c|c|}
\hline $\begin{array}{l}\text { Palicourea } \\
\text { marcagravii st. Hil. }\end{array}$ & Rubiaceae & light & $\begin{array}{l}\text { potentiality to form soil } \\
\text { seed banks; soil storage } \\
\text { favoured seed survival } \\
\text { and germination }\end{array}$ & $\begin{array}{l}\text { Araújo and Cardoso } \\
\text { (2007) }\end{array}$ \\
\hline $\begin{array}{l}\text { Platycyamus regnelli } \\
\text { Benth. }\end{array}$ & Fabaceae & indifferent & $\begin{array}{l}\text { ? (unknown); germination } \\
\text { is higher at } 25^{\circ} \mathrm{C} \text { and } 30^{\circ} \mathrm{C} \\
\text { and in roled paper and } \\
\text { between paper layers }\end{array}$ & Scalon et al. (1993) \\
\hline $\begin{array}{l}\text { Psychotria } \\
\text { hoffmansegiana (Wild. } \\
\text { ex. Roem. \& Schult.) } \\
\text { Mull. Arg. }\end{array}$ & Rubiaceae & light & $\begin{array}{l}\text { potentiality to form soil } \\
\text { seed banks; soil storage } \\
\text { favoured seed survival } \\
\text { and germination }\end{array}$ & $\begin{array}{l}\text { Araújo and Cardoso } \\
\text { (2007) }\end{array}$ \\
\hline P. vellosiana Benth. & Rubiaceae & light & $\begin{array}{l}\text { potentiality to form soil } \\
\text { seed banks; seeds show } \\
\text { true dormancy and/or } \\
\text { required an extended time } \\
\text { to germinate }\end{array}$ & $\begin{array}{l}\text { Araújo and Cardoso } \\
\text { (2006) }\end{array}$ \\
\hline $\begin{array}{l}\text { Solanum lycocarpum } \\
\text { St. Hil. }\end{array}$ & Solanaceae & ? (unknown) & $\begin{array}{l}\text { tegument impermeability; } \\
\text { allelopathic potential }\end{array}$ & $\begin{array}{l}\text { Monteiro and Ramos } \\
\text { (1997); Oliveira et al. } \\
\text { (2004); Aires et al. } \\
\text { (2005) }\end{array}$ \\
\hline $\begin{array}{l}\text { Stylosanthes } \\
\text { macrocephala M.B. } \\
\text { Ferri \& Souza Costa }\end{array}$ & Fabaceae & indifferent & $\begin{array}{l}\text { germination is higher } \\
\text { between } 20^{\circ} \mathrm{C} \text { and } 30^{\circ} \mathrm{C}\end{array}$ & Silva and Felippe (1986) \\
\hline $\begin{array}{l}\text { Vellozia leptopetala } \\
\text { Goeth. et Henr. }\end{array}$ & Velloziaceae & light & $\begin{array}{l}\text { campo rupestre } \\
\text { potentiality to form soil } \\
\text { seed banks; germination } \\
\text { in different temperatures } \\
\text { and light conditions }\end{array}$ & Garcia et al. (2007) \\
\hline $\begin{array}{l}\text { V. gigantea N.L. } \\
\text { Menezes \& Mello-Silva }\end{array}$ & Velloziaceae & light & $\begin{array}{l}\text { campo rupestreseeds } \\
\text { submitted to high light } \\
\text { intensities }\end{array}$ & Garcia and Diniz (2003) \\
\hline Zeyhera montana Mart. & Bignoniaceae & $\begin{array}{l}\text { ? (experiment } \\
\text { under } 12 \mathrm{~h} \\
\text { photoperiod) }\end{array}$ & $\begin{array}{l}\text { embrionic stretching and } \\
\text { possible presence of } \\
\text { inhibitors }\end{array}$ & Dousseau et al. (2007) \\
\hline
\end{tabular}

scarification, differences in the germination of seeds collected in faeces or in mature fruits were not detected. In both group of seeds, the percentage of germination was $70 \%$. The author observed that when the animal bites the fruit it causes damages to the seeds so that the percentage of seed germination should be higher than 70\% (Monteiro and Ramos, 1997).

Some seeds are sensitive to very high temperatures, similar to those registered during burnings. Seeds of Heteropterys pteropetala (Adr. Juss.), Malpighiaceae, collected in a natural area in Brasília ("Reserva Ecológica do IBGE” - RECOR, DF) showed to be sensitive to early burnings (areas of the RECOR submitted to biennial fires in June), as reported by Schmidt et al. (2005). The seeds were exposed to temperatures of $60^{\circ} \mathrm{C}$ during 40 minutes, $80^{\circ} \mathrm{C}$ during 10 minutes and $100^{\circ} \mathrm{C}$ during 2 minutes. None of these treatments interfered in the viability ( $\geq 80 \%$ ) nor in the germination of the seeds $(\geq 70 \%)$. Treatments of $100^{\circ} \mathrm{C}$ during 5 or 10 minutes and of $200^{\circ} \mathrm{C}$ during 1 minute reduced the germinability respectively in 50\%, 90\% and 100\%. In contrast, late burnings (area of the RECOR submitted to biennial fires towards the end of the dry period in September) had positive effects and caused increases in the number of individuals recruited (Schmidt et al., 2005). Oliveira (1998) observed that fire may interfere on the structure and the composition of species in a community through its effects on sexual reproduction. Nevertheless, few studies have been conducted using high temperatures 
similar to those found during the passage of fire.

Miconia albicans (Sw.) Triana (Gorla and Perez, 1997; Carreira and Zaidan, 2007), Andira humilis Mart. ex Benth (Periotto et al., 2004), S. lycocarpum (Oliveira et al., 2004, Aires et al., 2005) were considered to have allelopathic effects. From these, only the seeds of M. albicans were experimentally tested and showed to be affected by their own extracts (Carreira and Zaidan, 2007). These authors mentioned that field observations point to the hypothesis of an allelopathic effect on other plant species, considering that plants of the same species form homogenous groups and could inhibit the germination of certain seeds and the establishment of others. Dousseau et al. (2007) observed a kind of embryonary dormancy in seeds of Zeyera montana Mart. and discussed the possible presence of germination inhibitors, although the authors failed to isolate this inhibiting agent.

\section{TREE SPECIES}

The seeds of most of the species seem to have no light requirement to germinate, i.e. they do not show photoblastic response. Nevertheless, one must consider that in some studies the germination tests were conducted directly in the soil and the information about the light conditions during the experimental period was omitted. For this reason studies on seed germination of tree species of the Cerrado focus on methods of dormancy breaking and tegument impermability.

Seeds of most savanna trees are dormant and physical dormancy is the most common type (Baskin and Baskin, 2001). The impermeability of the tegument to water and oxygen is a kind of dormancy rather common in large seeds, and especially in those of the Fabaceae. This type of dormancy can be broken by scarification resulting in the rupture or weakness of the tegument, allowing the entrance of water and oxygen and thus leading to the starting of the germination process. There are many methods to surpass this type of dormancy like mechanical scarification using abrasive materials, incisions or damages in the tegument, stratification or exposition to high temperatures and chemical scarification by strong acids. Among these methods, sulphuric acid and incisions in the tegument proved to be the most efficient.

The seeds of Annona crassiflora Mart. exhibit embrionary dormancy that causes desuniformity in germination (Table 3). Dormancy is broken when the seeds are sunk in gibberellic acid (Bernardes et al., 2007). Seeds of Dipteryx alata Vog. need a period of post maturation inside the fruit to achieve high germinability (Corrêa et al., 2000).

Seeds of Eugenia calycina Cambess. and Tabebuia heptaphylla (Vell.) Toledo show low viability after harvest. These species are cultivated for fruit production and ornamental purposes, respectively. For this reason experiments aiming to obtain homegeneous plantlets in the field were carried out to test differents substrates (Büllow et al., 1994). Seeds of T. heptaphylla showed higher germinability int the presence of clay cerrado soils with or without organic matter (Bocchese et al., 2008).

Some seeds have peculiar requirements to germinate. This is the case of seeds of Peltophorum dubium Taub. and Pterogyne nitens Tul. Seeds of P. dubium are temperature-resistent: exposition for 24 hours at $45^{\circ} \mathrm{C}$ is sufficient to break the mechanical dormancy imposed by the tegument (Perez et al., 1998). Gibberellic acid allows an increase in the maximum tolerance to water stress especially in the presence of putrescin and espermidin, growth regulating substances that modulate some biological process such as cell division, responses to stressing factors and developmental processes (Botelho and Perez, 2001). Seeds of $P$. nitens are resistant to water stress and to several salt solutions (Nassif and Perez, 1997a). The seeds are tolerant to dryness between -2.4 and -2.6 MPa (manitol) and -1.0 and -1.2 MPa (PEG 6000). Using $\mathrm{CaCl}_{2}$ e $\mathrm{KCl}$ solutions, the maximum limit of tolerance is between -1.6 and -1.8 $\mathrm{MPa}$ and for $\mathrm{NaCl}$ solutions, between -2.0 and -2.2 MPa.

Felippe (1990b) and Godoy and Felippe (1992) studied the imbibition and the germination of the seeds of Qualea grandiflora Mart. and Q. cordata Spreng., respectively. The authors verified that both species have light colour and dark colour seeds the latter ones being more frequent. The light colour seeds imbibe more quickly than the dark colour seeds and their germinability is around $80 \%$. The tetrazolium test showed that only $2 \%$ of the dark colour seeds of Q. grandiflora are viable (Felippe, 1990b).

\section{CONCLUDING REMARKS}

The review of the more recent literature on seed germination of Cerrado species shows that the studies are limited to tests on seed responses to light (mainly 
Table 3. Light/dark requirement, type of dormancy and/or characteristics of seeds of herbaceous species of the Cerrado.

\begin{tabular}{|c|c|c|c|c|}
\hline Species & Family & $\begin{array}{l}\text { Light/Dark } \\
\text { requirement }\end{array}$ & $\begin{array}{l}\text { Type of dormancy and/or } \\
\text { other characteristics }\end{array}$ & Reference \\
\hline $\begin{array}{l}\text { Annona crassiflora } \\
\text { Mart. }\end{array}$ & Annonaceae & ? (unknown) & $\begin{array}{l}\text { embrionary; } \mathrm{GA}_{3} 1000 \\
\text { ppm was efficient to } \\
\text { break dormancy }\end{array}$ & Bernardes et al. (2007) \\
\hline $\begin{array}{l}\text { Astronium urundeuva } \\
\text { (Fr. All.) Engl. }\end{array}$ & Anacardiaceae & $\begin{array}{l}\text { ? (experiment } \\
\text { under } 12 \mathrm{~h} \\
\text { photoperiod) }\end{array}$ & $\begin{array}{l}\text { seeds are ortodox and } \\
\text { germination is higher at } \\
20^{\circ} \mathrm{C}\end{array}$ & $\begin{array}{l}\text { Medeiros and Cavallari } \\
\text { (1992) }\end{array}$ \\
\hline $\begin{array}{l}\text { Bowdichia virgilioides } \\
\text { Kunth }\end{array}$ & Fabaceae & ? (unknown) & $\begin{array}{l}\text { tegument impermeability; } \\
\text { best method for } \\
\text { dormancy break: } \\
\text { scarification with } \\
\text { sulphuric acid }\end{array}$ & $\begin{array}{l}\text { Smiderle and Sousa } \\
\text { (2003); Albuquerque et } \\
\text { al. (2007) }\end{array}$ \\
\hline $\begin{array}{l}\text { Caryocar brasiliensis } \\
\text { Camb. }\end{array}$ & Caryocaraceae & ? (unknown) & $\begin{array}{l}\text { undifferentiated } \\
\text { embryos; allelopathic } \\
\text { potential }\end{array}$ & $\begin{array}{l}\text { Sá e Carvalho et al. } \\
\text { (1994); Melo and } \\
\text { Gonçalves (2001) }\end{array}$ \\
\hline Cassia excelsa Schrad & Fabaceae & ? (unknown) & $\begin{array}{l}\text { tegument impermeability; } \\
\text { dormancy break with } \\
\text { sulphuric acid; highest } \\
\text { germinability achieved } \\
\text { after conditioning with } \\
\text { distilled water }\end{array}$ & $\begin{array}{l}\text { Jeller and Perez (1999); } \\
\text { Jeller et al. (2003) }\end{array}$ \\
\hline $\begin{array}{l}\text { Copaifera langsdorffii } \\
\text { Desf. }\end{array}$ & Fabaceae & ? (unknown) & $\begin{array}{l}\text { tegument impermeability; } \\
\text { seeds immersed in ether } \\
\text { and germination } \\
\text { inhibited by dry hot } \\
\text { application and boiled } \\
\text { treatment }\end{array}$ & Perez and Prado (1993) \\
\hline $\begin{array}{l}\text { Dalbergia miscolobium } \\
\text { Benth. } \\
(\text { sin. D. violacea) }\end{array}$ & Papilionaceae & indifferent & $\begin{array}{l}\text { germination is concluded } \\
\text { in } 6 \text { days }\end{array}$ & $\begin{array}{l}\text { Arasaki and Felippe } \\
\text { (1987) }\end{array}$ \\
\hline Dipteryx alata Vog. & Fabaceae & ? (unknown) & $\begin{array}{l}\text { post-maturation; no } \\
\text { variation in the \% of } \\
\text { plant emersion and } \\
\text { emersion velocity index }\end{array}$ & Corrêa et al. (2000) \\
\hline $\begin{array}{l}\text { Enterolobium } \\
\text { contorsiliquum (Vell.) } \\
\text { Morong. }\end{array}$ & Fabaceae & $\begin{array}{l}\text { ? (germination in } \\
\text { the soil) }\end{array}$ & $\begin{array}{l}\text { tegument impermeability; } \\
\text { better method for } \\
\text { dormancy break is } \\
\text { scarification with } \\
\text { sandpaper;Tmax } \\
\text { between } 40.9^{\circ} \mathrm{C} \text { and } \\
42.4^{\circ} \mathrm{C}\end{array}$ & $\begin{array}{l}\text { Eira et al. (1993); } \\
\text { Monteiro and Ramos } \\
\text { (1997)Lima et al.(1997) }\end{array}$ \\
\hline $\begin{array}{l}\text { Eugenia dysenterica } \\
\text { Mart. ex. DC. }\end{array}$ & Myrtaceae & indifferent & $\begin{array}{l}\text { better results with sandy } \\
\text { and clay; larger seeds } \\
\text { from apparently more } \\
\text { vigorous fruits }\end{array}$ & $\begin{array}{l}\text { Nietsche et al. (2004); } \\
\text { Duarte et al. (2006); } \\
\text { Martinotto et al. (2007) }\end{array}$ \\
\hline E. calycina Cambess. & Myrtaceae & ? (unknown) & $\begin{array}{l}\text { ? (unknown); loses } \\
\text { viability quickly }\end{array}$ & Bülow et al. (1994) \\
\hline $\begin{array}{l}\text { Kielmeyera coriacea } \\
\text { Mart. }\end{array}$ & Guttiferae & ? (unknown) & $\begin{array}{l}\text { higher viability when } \\
\text { kept in cold conditions }\end{array}$ & $\begin{array}{l}\text { Botelho and Carneiro } \\
\text { (1992) }\end{array}$ \\
\hline Miconia rubiginosa & Melastomatace & light & germination \% is higher & Carreira and Zaidan \\
\hline
\end{tabular}


(Bonpl.) DC.

Myracrodruon

urundeuva Allemão under light and between

$20^{\circ} \mathrm{C}$ and $30^{\circ} \mathrm{C}$

? (unknown);

polyembriony;

stratificationduring six

days; germination \% is

higher in vermiculite

and coconut fiber

substrates

\begin{tabular}{|c|c|c|c|c|}
\hline $\begin{array}{l}\text { Ouratea spectabilis } \\
\text { (mart.) Engl. }\end{array}$ & Ochnaceae & ? (unknown) & allelopathic potential & Silva et al. (2006) \\
\hline $\begin{array}{l}\text { Peltophorum dubium } \\
\text { Taub. }\end{array}$ & Fabaceae & indifferent & $\begin{array}{l}\text { tegument impermeability; } \\
\text { thermo-resistant; } \mathrm{GA}_{3} \\
\text { extended the maximal } \\
\text { tolerance limit to water } \\
\text { stress }\end{array}$ & $\begin{array}{l}\text { Perez et al. (1998; 1999); } \\
\text { De Fiore and Perez } \\
\text { (2000); Botelho et al. } \\
\text { (2001) }\end{array}$ \\
\hline $\begin{array}{l}\text { Platypodium elegans } \\
\text { Vog. }\end{array}$ & Fabaceae & ? (unknown) & $\begin{array}{l}\text { tegument } \\
\text { impermeability; } \\
\text { longitudinal cuts } \\
\text { promote higher } \\
\text { indices of germination } \\
\text { speed }\end{array}$ & Pacheco et al. (2007) \\
\hline $\begin{array}{l}\text { Pouteria ramiflora } \\
\text { (Mart.) Radlk. }\end{array}$ & Sapotaceae & ? (unknown) & allelopathic potential & Silva et al. (2006) \\
\hline Pterogyne nitens Tul. & Fabaceae & ? (unknown) & $\begin{array}{l}\text { tegument impermeability; } \\
\text { best method for } \\
\text { dormancy break is } \\
\text { scarification with } \\
\text { sulphuric acid; tolerance } \\
\text { to salt solutions }\end{array}$ & $\begin{array}{l}\text { Nassif and Perez } \\
\text { (1997a; 1997b; 2000) }\end{array}$ \\
\hline $\begin{array}{l}\text { Qualea grandiflora } \\
\text { Mart. }\end{array}$ & Vochysiaceae & indifferent & $\begin{array}{l}\text { dark seeds with no } \\
\text { embryos; allelopathic } \\
\text { potential }\end{array}$ & $\begin{array}{l}\text { Felippe (1990b); Silva } \\
\text { et al. (2006) }\end{array}$ \\
\hline Q. cordata Spreng. & Vochysiaceae & ? (unknown) & $\begin{array}{l}\text { dark seeds with no } \\
\text { embryos }\end{array}$ & $\begin{array}{l}\text { Godoy and Felippe } \\
\text { (1992) }\end{array}$ \\
\hline $\begin{array}{l}\text { Senna macranthera } \\
\text { (Collad.) Irwin et. Barn. }\end{array}$ & Fabaceae & ? (unknown) & $\begin{array}{l}\text { tegument impermeability; } \\
\text { immersion in sulphuric } \\
\text { acid }\end{array}$ & $\begin{array}{l}\text { Eschiapati-Ferreira and } \\
\text { Perez (1997) }\end{array}$ \\
\hline $\begin{array}{l}\text { Shiphoneugena } \\
\text { densiflora Berg. }\end{array}$ & Myrtaceae & $\begin{array}{l}\text { ? (germination in } \\
\text { the soil) }\end{array}$ & $\begin{array}{l}\text { ? (unknown); depulped } \\
\text { fruits germinated twice } \\
\text { as much as intact fruits }\end{array}$ & $\begin{array}{l}\text { Monteiro and Ramos } \\
\text { (1997) }\end{array}$ \\
\hline $\begin{array}{l}\text { Stryphnodendron } \\
\text { adstringens (Mart.) } \\
\text { Coville }\end{array}$ & Fabaceae & ? (unknown) & allelopathic potential & $\begin{array}{l}\text { Barreiro et al. (2005); } \\
\text { Silva et al. (2006) }\end{array}$ \\
\hline $\begin{array}{l}\text { Tabebuia } \\
\text { heptaphylla (Vell.) } \\
\text { Toledo }\end{array}$ & Bignoniaceae & $\begin{array}{l}\text { ? (experiment } \\
\text { under a shaded } \\
\text { house) }\end{array}$ & $\begin{array}{l}\text { low viability; higher seed } \\
\text { germination rates in clay } \\
+ \text { organicmaterial and } \\
\text { clay soils }\end{array}$ & Bocchese et al. (2008) \\
\hline Talauma ovata St. Hil. & Magnoliaceae & $\begin{array}{l}\text { ? (germination in } \\
\text { the soil) }\end{array}$ & $\begin{array}{l}\text { ? (unknown); germination } \\
\text { is less than } 50 \% \text { with or } \\
\text { without aril }\end{array}$ & $\begin{array}{l}\text { Monteiro and Ramos } \\
\text { (1997) }\end{array}$ \\
\hline $\begin{array}{l}\text { Tapura amazonica } \\
\text { Poepp. and Endl. }\end{array}$ & Dichapetalaceae & $\begin{array}{l}\text { ? (germination in } \\
\text { the soil) }\end{array}$ & $\begin{array}{l}\text { ? (unknown); mechanical } \\
\text { seed coat scarification }\end{array}$ & $\begin{array}{l}\text { Monteiro and Ramos } \\
\text { (1997) }\end{array}$ \\
\hline
\end{tabular}

(2007)

Medeiros et al. (2000);

Silva et al. (2002);

Dorneles et al. (2005);

Pacheco et al. (2006) 
seeds of herbaceous and shrub species), optimum or cardinal temperatures, and methods to break dormancy and tegument impermeability (especially in seeds of tree species). Very few information on the physiological and biochemical aspects of reserve compounds of the seeds of Cerrado species are available. Few studies on seed germination had been conducted using high temperatures. Borghetti (2005) discussed the germination of seeds from species occurring in different regions of Brazil. The author concluded that very few seeds germinate above $40^{\circ} \mathrm{C}$, but seeds from Cerrado, Caatinga and Restinga show maximum temperature for germination near $40^{\circ} \mathrm{C}$.

Fire is an important environmental factor in the Cerrado, either of natural origin or started intentionally by humans. One effect of fire is to stimulate and synchronize flowering and thus seed production mainly in shrub and herbaceous species (Coutinho 1982). Another effect of fire is to remove litter and thus creating ideal conditions for seed germination such as increases in soil temperature, in the amplitude of fluctuations of daily temperature (Coutinho 1990), exposition of bare mineral soil and increases of light availability. Fire may also accelerate fruit drying and thus anticipate the release of the seeds, as recently described in fruits of Kielmeyera coriacea Mart. (Cirne and Miranda 2009). During the fire, fruit surface temperatures as high as $720^{\circ} \mathrm{C}$ were measured but maximum internal fruit temperatures were around $60^{\circ} \mathrm{C}$. Mature fruits of $K$. coriacea have high water content and the evaporation of moisture during exposition to the flames or to the hot air prevent internal temperature from rising above $100^{\circ} \mathrm{C}$ until the fruit tissue has dried. The authors also show that seeds released after fire present higher germinability than viable seeds from fruits that were open before the fire. Heat from fires may also break physical dormancy in seeds, as described for some seeds of the Australian and African savanna tree species. Nevertheless, there is a lack of information about fire effects on the germination of seeds of Brazilian cerrado species.

Very few researchers pay attention to germination of seeds under natural conditions, such as Labouriau and his collaborators in the 1960's, and use this information to establish experimental conditions in the laboratory. Studies on soil seed banks are scarce and the few results described point that in general only the small seeds of Cerrado species can remain viable when buried in the soil, thus forming permanent or transitory soil banks.

\section{REFERENCES}

Abreu EMP, Garcia QS (2005) Efeito da luz e da temperatura na germinação de sementes de espécies de Xyris L. (Xyridaceae) ocorrentes na Serra do Cipó, MG, Brasil. Acta Bot. Bras. 19:149-154.

Aires SS, Ferreira AF, Borghetti F (2005) Efeito alelopático de folhas e frutos de Solanum lycocarpum A. St.-Hil. (Solanaceae) na germinação e crescimento de Sesamum indicum L. (Pedaliaceae) em solo sob três temperaturas. Acta Bot. Bras. 19:339-344.

Albuquerque KS, Guimarães RM, Almeida IF, Clemente ACS (2007) Métodos para a superação da dormência em sementes de sucupira-preta (Bowdichia virgilioides Kunth.). Ciênc. Agrotec. 31:1716-1721.

Alves MCS, Medeiros-Filho S, Andrade-Neto M, Teófilo EM (2000) Superação da dormência em sementes de Bauhinia monandra Britt. e Bauhinia ungulata L. Caesalpinoideae. Rev. Bras. Sem. 22:139-144.

Arasaki FR, Felippe GM (1987) Germinação de Dalbergia violacea, uma espécie dos cerrados. Rev. Bras. Biol. 47:457-463.

Araújo CC, Cardoso VJM (2006) Storage in cerrado soil and germination of Psychotria vellosiana (Rubiaceae). Braz. J. Biol. 66:709-717.

Araújo CC, Cardoso VJM (2007) Psychotria hoffmansegiana (Willd ex Roem. \& Schult.) Mull. Arg. and Palicourea marcagravii st. Hil. (Rubiaceae): potential for forming soil seed banks in a Brazilian Cerrado. Braz. J. Biol. 67:421-427.

Arrigoni-Blank MF, Carvalho DA, Alvarenga AA, Laura VA, Blank AF (1997) Fenologia e germinação de guabiroba [Campomanesia pubescens (DC.) Berg:]: espécie de cerrado. Ciênc. Agrotec. 21:237-241.

Barbosa EG, Pivello VR, Meirelles ST (2008) Allelopathic evidence in Brachiaria decumbens and its potential to invade the Brazilian cerrados. Braz. Arch. Biol. Technol. 51:625-631.

Barreiro AP, Delachiave MEA, Souza FS (2005) Efeito alelopático de extratos de parte aérea de barbatimão [Stryphnodendron adstringens (Mart.) Coville] na germinação e desenvolvimento da plântula de pepino. Rev. Bras. Plan. Med. 8:4-8.

Baskin, CC, Baskin JM (2001) Seeds. London, Academic Press.

Bernardes TG, Estrêla CT, Naves RV, Rezende CFA, 
Mesquita MAM, Pires LL (2007) Efeito do armazenamento e de fitohormônios na qualidade fisiológica de sementes de araticum (Annona crassiflora Mart.). Pesq. Agropec. Trop. 37:163-168.

Bocchese RA, Oliveira AKM, Melotto AM, Fernandes V, Laura VA (2008) Efeito de diferentes tipos de solos na germinação de sementes de Tabebuia heptaphylla, em casa telada. Cerne 14:62-67.

Borghetti F. (2005) Temperaturas extremas e a germinação das sementes. In: Nogueira RJMC, Araújo EL, Willadino LG, Cavalcante UMT (orgs.), Estresses Ambientais: Danos e Benefícios em Plantas, pp.207218. MXM Gráfica e Editora, Recife.

Botelho SA, Carneiro JGA (1992) Influência da umidade, embalagens e ambientes sobre a viabilidade e vigor de sementes de pau-santo (Kielmeyera coriacea Mart.) Rev. Bras. Sem. 14:41-46.

Botelho BA, Perez SCJGA (2001) Estresse hídrico e reguladores de crescimento na germinação de sementes de canafístula. Sci. Agric. 58:43-49.

Bülow JFW, Carmona R, Parente TV (1994) Armazenamento e tratamento de sementes de pitangavermelha-do-cerrado (Eugenia calycina). Pesq. Agropec. Bras. 29:961-970.

Carreira RC, Zaidan LBP (2003) Estabelecimento e crescimento inicial de Miconia albicans (Sw.) Triana e Schizocentron elegans Meissn., sob fotoperíodos controlados. Hoehnea 30:155-161.

Carreira RC, Zaidan LBP (2007) Germinação de sementes de espécies de Melastomataceae de Cerrado sob condições controladas de luz e temperatura. Hoehnea 34:261-269.

Cesarino F, Zaidan LBP (1998) Vernonia cognata Less. (Asteraceae): armazenamento e viabilidade dos aquênios. Hoehnea 25:59-70.

Cesarino F, Araujo JE, Zaidan LBP (1998) Germinação de sementes e crescimento de plantas de Diplusodon virgatus Pohl, Lythraceae. Acta Bot. Bras. 12:349-356.

Cirne P, Miranda HS (2009) Effects of prescribed fires on the survival and release of seeds of Kielmeyera coriacea (Spr.) Mart. (Clusiaceae) in savannas of Central Brazil. Braz. J. Plant Physiol. (in press).

Corrêa GC, Rocha MR, Naves RV (2000) Germinação de sementes e emergência de plântulas de baru (Dipterys alata Vog.) nos cerrados do Estado de Goiás. Pesq. Agropec. Trop. 30:17-23.
Coutinho LM (1982) Ecological effects of fire in Brazilian cerrado. In: Huntley BJ, Walker BH (eds), Ecology of Tropical Savannas, pp.273-291. Springer Verlag, Berlin.

Coutinho LM (1990) Fire in the ecology of Brazilian cerrado. In: Goldammer JG (ed), Fire in the Tropical Biota, Ecological Studies, pp. 82-105. Springer Verlag, Berlin.

Coutinho LM (2002) O bioma do cerrado. In: Klein AL (org), Eugen Warming e o Cerrado Brasileiro: Um Século Depois, pp.77-91. Editora UNESP, São Paulo.

De Fiore A, Perez SCJGA (2000) Emergência em campo e germinação de Peltophorum dubium (Spreng.) Taub. Fabaceae (canafístula) sob diferentes temperaturas com o uso de reguladores de crescimento. Rev. Inst. Flor. 12:119-126.

Dietz JM (1984) Ecology and social organization of the manned wolf (Chrysocyum brachyurus). Smith. Contr. Zool. 392:1-51.

Dousseau S, Alvarenga AA, Castro EM, Arantes LO, Nery FC (2007) Superação de dormência em sementes de Zeyhera montana Mart. Ciênc. Agrotec. 31:17441748.

Duarte EF, Naves RV, Borges JD, Guimarães NNR (2006) Germinação e vigor de sementes de cagaita (Eugenia dysenterica Mart. ex. DC.) em função de seu tamanho e tipo de coleta. Pesq. Agropec. Trop. 36:173-179.

Eschiapati-Ferreira MS, Perez SCJGA (1997) Tratamentos para superar a dormência de sementes de Senna macranthera (Collad.) Irwin et. Barn. (FabaceaeCaesalpinoidea). Rev. Bras. Sem. 19:231-237.

Felippe GM (1990a) Germinação de Bidens gardneri Baker, uma planta anual dos cerrados. Hoehnea 17:7-11.

Felippe GM (1990b) Qualea grandiflora: the seed and its germination. Rev. Bras. Bot. 13:33-37.

Felippe GM, Filgueiras T (1986) Germination of Actinocladum verticilatum (Ness) McClure ex Soderstrom, a bamboo from the Brazilian cerrado vegetation: short communication. Hoehnea 13: 95-100.

Felippe GM, Silva JCS (1984) Estudos de germinação em espécies do cerrado. Rev. Bras. Bot. 7:157-163.

Ferri MG (1960) Nota preliminar sobre a vegetação do cerrado em Campo Mourão, Paraná. Bol. Fac. Filos. Ciênc. Let. 17:109-115.

Garcia QS, Diniz ISS (2003) Comportamento germinativo de três espécies de Vellozia da Serra do Cipó, MG. Acta Bot. Bras. 17:487-494. 
Garcia QS, Jacobi CM, Ribeiro BA (2007) Resposta germinativa de duas espécies de Vellozia (Velloziaceae) dos campos rupestres de Minas Gerais, Brasil. Acta Bot. Bras. 21:451-456.

Giulietti AM, Menezes NL, Pirani JR, Meguro M,Wanderley MGL (1987) Flora da Serra do Cipó, Minas Gerais: caracterização e lista de espécies. Bol. Bot. Univ. São Paulo 9:1-151.

Godoy SMA, Felippe GM (1992) Qualea cordata: a semente e sua germinação. Rev. Bras. Bot. 15:17-21.

Gomes V, Fernandes GW (2002) Germinação de aquênios de Baccharis dracunculifolia D.C. (Asteraceae). Acta Bot. Bras. 16:421-427.

Gorla CM, Perez SCJGA (1997) Influência e extratos aquosos de Miconia albicans Triana, Lantana camara L., Leucaena leucocephala (Lam) de Wit e Drimys winteri Forst, na germinação e crescimento de sementes de tomate e pepino. Rev. Bras. Sem. 19:261-266.

Jeller H, Perez SCJGA (1999) Estudo da superação da dormência e da temperatura em sementes de Cassia excelsa Schrad. Rev. Bras. Sem. 21: 32-40.

Jeller H, Perez SCJGA, Raizer J (2003) Water uptake, priming, drying and storage effects in Cassia excelsa Schrad seeds. Braz. J. Biol. 63:61-68.

Klink CA (1996) Germination and seedling establishment of two native and one invading African species in the Brazilian cerrado. J. Trop. Ecol. 12:139-147.

Lara ACF, Fernandes GW (1996) The highest diversity of galling insects: Serra do Cipó, Brazil. Biodiver. Letters 3:111-114.

Labouriau LG, Válio LFM, Labouriau MLS, Handro W (1963) Nota sobre a germinação de sementes de plantas de cerrado em condições naturais. Rev. Bras. Biol. 23:227-234.

Labouriau LG, Válio IFM, Heringer EP (1964) Sobre o sistema reprodutivo de plantas dos cerrados. An. Acad. Bras. Ci. 36:449-464.

Lima CMR, Borghetti F, Sousa MV (1997) Temperature and germination of the leguminosae Enterolobium contortisiliquum. Rev. Bras. Fisiol. Veg. 9: 97-102.

Mantovani W, Martins FR (1988) Variações fenológicas das espécies do cerrado da Reserva Biológica de Moji Guaçu, Estado de São Paulo. Rev. Bras. Bot. 11:101-112.

Martinotto C, Paiva R, Santos BR, Soares FP, Nogueira RC, Silva AAN (2007) Efeito da escarificação e luminosidade na germinação in vitro de sementes de cagaiteira (Eugenia dysenterica DC.). Ciênc. Agrotec. 31:1668-1671.

Medeiros ACS, Cavallari DAN (1992) Conservação de germoplasma de aroeira (Astronium urundeuva (Fr. All.) Engl. I. Germinação de sementes após imersão em nitrogênio líquido $\left(-196^{\circ} \mathrm{C}\right)$. Rev. Bras. Sem. 14:73-75.

Medeiros ACS, Smith R, Probert R, Sader R (2000) Comportamento fisiológico de sementes de aroeira (Myracrodruon urundeuva Fr. All.) em condições de armazenamento. Bol. Pesq. Flor. 40:85-98.

Melchior SJ, Custódio CC, Marques TC, Machado Neto NB (2006) Colheita e armazenamento de sementes de gabiroba (Campomanesia adamantium Camb. Myrtaceae) e implicações na germinação. Rev. Bras. Sem. 28:141-150.

Melo JT, Gonçalves NA (2001) Inibidores de germinação em frutos e sementes de pequi. Boletim de pesquisa e desenvolvimento, EMBRAPA Cerrados, n. 23.

Melo JT, Silva JA, Torres RAA, Silveira CES, Caldas LS (1998) Coleta, propagação e desenvolvimento inicial de espécies do cerrado. In: Sano SM, Almeida SP (orgs), Cerrado: ambiente e flora, pp.195-246. EMBRAPA, Brasília.

Mittermeier RA, Myers N, Gil PR, Mittermeier CG (1999) Hotspots: Earth's Biologically Richest and Most Endangered Terrestrial Ecoregions. CEMEX, Mexico City.

Monteiro PPM, Ramos FA (1997) Beneficiamento e quebra de dormência de sementes em cinco espécies florestais de Cerrado. R. Árvore 21:169-174.

Nassif SML, Perez SCJGA (1997) Germinação de sementes de amendoim-do-campo (Pterogyne nitens Tul. Fabaceae-Caesalpinoideae) submetidas a diferentes condições de estresse hídrico e salino. Rev. Bras. Sem. 19:143-150.

Nassif SML, Perez SCJGA (1997) Germinação de sementes de amendoim-do-campo (Pterogyne nitens Tul.): influência dos tratamentos para superar a dormência e profundidade de semeadura. Rev. Bras. Sem. 19:172179.

Nassif SML, Perez SCJGA (2000) Efeitos da temperatura na germinação de sementes de amendoimdo-campo (Pteronyne nitens Tul.). Rev. Bras. Sem. 22:1-6.

Nietsche S, Gonçalves VD, Pereira MCT, Santos FA, Abreu SC, Mota WF (2004) Tamanho da semente e substratos na germinação e crescimento inicial de 
mudas de cagaiteira. Ciênc. Agrotec. 28:1321-1325.

Nogueira RC, Paiva R, Castro AH, Vieira CV, Abbade LC, Alvarenga AA (2004) Germinação in vitro de muricipequeno (Byrsonima intermedia A. Juss.). Ciênc. Agrotec. 28:1053-1054.

Oliveira PE (1998) Fenologia e biologia reprodutiva das espécies de cerrado. Pp. 169-192. In: S.M. Sano \& S.P. de Almeida. Cerrado: ambiente e flora. Brasília, EMBRAPA.

Oliveira PG, Garcia QS (2005) Efeitos da luz e da temperatura na germinação de sementes de Syngonanthus elegantulus Ruhland, S. elegans (Bong.) Ruhland e $S$. venustus Silveira (Eriocaulaceae). Acta Bot. Bras. 19:639-645.

Oliveira SCC, Ferreira AF, Borghetti F (2004) Efeito alelopático de folhas de Solanum lycocarpum A. St.Hil. (Solanaceae) na germinação e crescimento de Sesamum indicum L. (Pedaliaceae) sob diferentes temperaturas. Acta Bot. Bras. 18:401-206.

Pacheco MV, Matos VP, Ferreira RLC, Feliciano ALP, Pinto KM (2006) Efeito de temperatura e substratos na germinação de sementes de Myracrodruon urundeuva Fr. All. (Anacardiaceae). R. Árvore 30:359-367.

Pacheco MV, Matos VP, Barbosa MD, Ferreira RLC, Passos MAA (2007) Germinação de sementes de Platypodium elegans Vog. submetidas a diferentes tratamentos pré-germinativos e substratos. Rev. Bras. Eng. Agr. Amb. 11:497-501.

Pereira TS (1992) Germinação de sementes de Bauhinia forficata Link. (Leguminosae Caesaspinoideae). Rev. Bras. Sem. 14:77-82.

Pereira-Diniz SG, Ranal MA (2006) Germinable soil seed bank of a gallery forest in Brazilian Cerrado. Plant Ecol. 183:337-348.

Perez SCJGA, Prado CHBA (1993) Efeitos de diferentes tratamentos pré-germinativos e da concentração de alumínio no processo germinativo de sementes de Copaifera langsdorffii Desf. Rev. Bras. Sem. 15:115118.

Perez SCJGA, Fanti SC, Casali CA (1998) Limites de temperatura e estresse térmico na germinação de sementes de Peltophorum dubium (Spreng) Taubert. Rev. Bras. Sem. 20:134-142.

Perez SCJGA, Fanti SC, Casali CA (1999) Dormancy break and light quality effects on seed germination of Peltophorum dubium Taub. R.Árvore 23:131-137.
Perez SCJGA, Fanti SC, Casali CA (2001) Influência da luz na germinação de sementes de canafístula submetidas a estresse hídrico. Bragantia 60:155-166.

Periotto F, Perez SCJGA, Lima MIS (2004) Efeito alelopático de Andira humilis Mart. ex Benth na germinação e no crescimento de Lactuca sativa L. e Raphanus sativus L. Acta Bot. Bras. 18:425-430.

Pivello VR, Carvalho VMC, Lopes PF, Peccinini AA, Rosso S (1999) Abundance and distribution of native and invasive alien grasses in a "cerrado" (Brazilian savanna) biological reserve. Biotropica 31:71-82.

Radford AE, Dickson WC, Massey JR, Bell CR (1976) Vascular Plant Systematics. Harper \& Row, New York.

Ranieri BD, Lana TC, Negreiros D, Araújo LM, Fernandes GW (2003) Germinação de sementes de Lavoisiera cordata Cogn. e Lavoisiera francavillana Cogn. (Melastomataceae) espécies simpátricas da Serra do Cipó, Brasil. Acta Bot. Bras. 17:523-530.

Rondon JN, Sassaki RM, Zaidan LBP, Felippe GM (2001) Effects of moisture content and temperature during storage on germination of the achenes of Bidens gardneri Baker. Rev. Bras. Bot. 24:35-41.

Sá e Carvalho CG, Ribeiro MC (1994) Efeitos de choques térmicos na germinação de Paepalanthus specious Koern. (Eriocaulaceae). Acta Bot. Bras. 8:205-211.

Sá e Carvalho CG, Cotes RA, Carneiro IF, Borges JD (1994) Efeitos de diferentes tratamentos na germinação do pequi (Caryocar brasiliensis Camb.). Acta Bot. Bras. 8:109-120.

Salomão NA, Davide AC, Firetti F, Sousa e Silva FC, Caldas LS, Wetzel MMVS, Torres RAA, Gonzáles S (2003) Germinação de sementes e produção de mudas de plantas do Cerrado. Rede de Sementes do Cerrado, Brasília.

Sassaki RM, Rondon JN, Zaidan LBP, Felippe GM (1999a) Germination of seeds from herbaceous plants artificially stored in cerrado soil. Rev. Bras. Biol. 59:271-279.

Sassaki RM, Zaidan LBP, Felippe GM (1999b) Effect of storage of achenes of Bidens gardneri Baker on light sensitivity during germination. Rev. Bras. Bot. 22:7581.

Sassaki RM, Rondon JN, Zaidan LBP, Felippe GM (1999c) Number of buried seeds and seedlings emergence in cerradao, cerrado and gallery forest soils at Pedregulho, Itirapina (SP), Brazil. Rev. Bras. Bot. 22:147-152. 
Scalon SPQ, Alvarenga AA, Davide AC (1993) Influência do substrato, temperatura, umidade e armazenamento sobre a germinação de sementes de pau-pereira (Platycyamus regnelli Benth). Rev. Bras. Sem. 15:143-146.

Schmidt IB, Sampaio AB, Borghetti F (2005) Efeitos da época de queima sobre a reprodução sexuada e estrutura populacional de Heteropterys pteropetala (Adr. Juss.), Malpighiaceae, em áreas de Cerrado sensu stricto submetidas a queimas bienais. Acta Bot. Bras. 19:927-934.

Schmidt IB, Figueiredo IB, Borghetti F, Scariot AO (2008) Produção e germinação de sementes de "capim dourado", Syngonanthus nitens (Bong.) Ruhland (Eriocaulaceae): implicações para o manejo. Acta Bot. Bras. 22: 37-42.

Silva JCS, Felippe GM (1986) Germination of Stylosanthes macrocephala. Rev. Bras. Bot. 9:263-268.

Silva LMM, Rodrigues TJD, Aguiar IB (2002) Efeito da luz e da temperatura na germinação de sementes de aroeira (Myracrodruon urundeuva Allemão). R. Árvore 26:691-697.
Silva GB, Martim L, Silva CL, Young MCM, Ladeira AM (2006) Potencial alelopático de espécies arbóreas nativas do Cerrado. Hoehnea 33:331-338.

Silveira FAO, Negreiros D, Fernandes GW (2004) Influência da lus e da temperatura na germinação das sementes de Marcetia taxifolia (A. St.-Hil) DC. (Melastomataceae). Acta Bot. Bras. 18:847-851.

Smiderle OJ, Sousa RCP (2003) Dormência em sementes de paricarana (Bowdichia virgilioides Kunth Fabaceae - Papilionidae). Rev. Bras. Sem. 25:48-52.

Válio IFM, Moraes V (1966). Sobre o sistema reprodutivo de plantas dos Cerrados. - II Simpósio sobre o cerrado. An. Acad. Bras. Cienc. 38:219-224.

Velten SB, Garcia QS (2005) Efeitos da luz e da temperatura na germinação de sementes de Eremanthus (Asteraceae), ocorrentes na Serra do Cipó, MG, Brasil. Acta Bot. Bras. 19:753-761.

Vieira DCM, Socolowski F, Takaki M (2007) Germinação de sementes de Dychia tuberosa (Vell.) Beer (Bromeliaceae) sob diferentes temperaturas em luz e escuro. Rev. Bras. Bot. 30:183-188. 